\title{
Augmentation of the effects of insulin and insulin-like growth factors I and II on glucose uptake in cultured rat skeletal muscle cells by sulfonylureas
}

\author{
P. H. Wang, F. Beguinot and R.J.Smith \\ The Joslin Research Laboratory and the Department of Medicine at the Brigham and Women's Hospital, Harvard Medical School, \\ Boston, Massachusetts, USA
}

\begin{abstract}
Summary. The effect of sulfonylureas on long-term regulation of glucose uptake by insulin and insulin-like growth factors has been studied in the L6 line of cultured skeletal muscle cells. These cells have previously been shown to possess many characteristics of differentiated skeletal muscle and to bind and respond to physiological concentrations of insulin and insulin-like growth factors I and II. Tolazamide (halfmaximal at $0.2 \mathrm{mg} / \mathrm{ml}$ ) augments the effects of insulin, insulin-like growth factor I, and insulin-like growth factor II on glucose uptake, increasing both sensitivity and maximal efficacy of the hormones. In the absence of added hormone, tolazamide has no effect on glucose uptake. A similar increase in insulin-stimulated glucose uptake with unaltered basal uptake occurs with glyburide (half-maximal at $0.5 \mu \mathrm{g} / \mathrm{ml}$ ). The action of tolazamide requires long-term exposure to the sulfonylurea $(22 \mathrm{~h}$ ) and is inhibited by cycloheximide, suggesting a process that involves new protein synthesis. In contrast
\end{abstract}

to glucose uptake, amino acid uptake in L6 cells is increased by tolazamide in the absence of hormones. Insulin and the insulin-like growth factors also stimulate amino acid uptake, but this effect is not further augmented by tolazamide. Thus, sulfonylureas appear to directly modulate amino acid uptake, but to indirectly augment glucose uptake through an effect on insulin and insulin-like growth factor stimulated pathways. Neither insulin binding nor insulin degradation is altered by tolazamide, indicating a post-binding mechanism of action. The L6 cultured skeletal muscle cell line should be useful in future studies on the mechanism of the extrapancreatic actions of sulfonylureas.

Key words: Amino acid uptake, glucose uptake, glyburide, insulin, insulin-like growth factor I, insulin-like growth factor II, skeletal muscle cells, sulfonylureas, tolazamide.
Sulfonylureas have been used in the management of diabetes mellitus since the discovery of their hypoglycaemic actions more than 30 years ago [1], yet their mechanism or mechanisms of action remain undefined. It was initially thought that sulfonylureas act solely on pancreatic B cells, since they were noted to increase insulin levels in Type 2 (non-insulin dependent) diabetic patients [2] and to be ineffective in Type 1 (insulin-dependent) diabetic patients who totally lack endogenous insulin [3]. Subsequently, it was found that sulfonylureas also can augment the effectiveness of insulin in peripheral, extrapancreatic tissues. This alternative site of sulfonylurea action was first suggested by the observation that chronic sulfonylurea administration in Type 2 diabetic patients results in improved glucose tolerance in the absence of elevated insulin levels [4]. Further in vivo studies have documented increased insulin-stimulated total body glucose utilisation [5, 6] and increased insulin-stimulated glucose transport [7]. In addition, in vitro obser- vations have demonstrated sulfonylurea effects in adipocytes [8, 9], fibroblasts [10, 11], hepatocytes [12, 13], IM-9 lymphocytes [10], breast cancer cells [10], and BC3H-1 muscle cells [14]. Although there are discordant results in the literature [15], the weight of experimental evidence indicates that sulfonylureas act in part by increasing sensitivity to insulin in peripheral tissues. Initial studies on the effects of sulfonylureas in peripheral tissues concentrated on possible changes in insulin receptor number $[10,11,16,17]$ but recent attention has focused on post-receptor actions [5, 8, 12, 13].

In evaluating the role of extrapancreatic tissues in mediating hypoglycaemic responses, it is important to consider the effects of sulfonylureas in skeletal muscle. Because of the large mass of muscle in comparison with other organs, insulin-stimulated pathways in skeletal muscle, such as glucose uptake, have significant influence on total body glucose homeostasis [18]. Current evidence suggests that glucose transport regulation includes a rapid, short-term response that is as- 
sociated with the recruitment of glucose transporters or alterations in intrinsic activity, and a gradual, longterm response that probably involves changes in the total number of glucose transporters [19]. It is likely that these different regulatory events are mediated by distinct molecular mechanisms. Insulin regulates glucose transport through both rapid and chronic mechanisms [19]. Sulfonylureas can augment rapid insulin-mediated changes in glucose uptake in peripheral tissues [7, 8], but it is not known whether sulfonylureas can augment long-term insulin effects on glucose uptake. For this reason, we have characterised the effects of sulfonylureas on long-term glucose transport regulation in the insulin-responsive L6 rat skeletal muscle cell line [20]. Since insulin-like metabolic actions in L6 cells are mediated by distinct receptors for insulin, insulin-like growth factor I (IGF I), and IGF II in L6 cells [21], we have evaluated the effects of sulfonylureas on responsiveness to all three of these hormones.

\section{Materials and methods}

\section{Materials}

Cell culture medium and bovine serum were purchased from GIB$\mathrm{CO}$ (Grand Island, NY). ${ }^{14} \mathrm{C}-2$-deoxy-D glucose $\left({ }^{14} \mathrm{C}-2-\mathrm{DG}, 51.5 \mathrm{Ci} /\right.$ mol), ${ }^{14} \mathrm{C}$-alpha-aminoisobutyric acid $\left({ }^{14} \mathrm{C}\right.$-AIB, $\left.53 \mathrm{Ci} / \mathrm{mol}\right)$, and ${ }^{125} \mathrm{I}$ monoiodoinsulin $(100 \mathrm{Ci} / \mathrm{g})$ were from New England Nuclear (Boston, Mass). Sodium tolazamide and potassium glyburide were from Upjohn (Kalamazoo, Mich) and porcine insulin was from Eli Lilly (Indianapolis, Ind). Recombinant (thr 59) IGF I was purchased from AmGen (Thousand Oaks, Calif). Rat IGF II of $\mathrm{M}_{\mathrm{r}} 8700$ (alternatively designated peak II multiplication-stimulating activity) was purified from conditioned medium of BRL-3A cells by a modification of the procedure of Moses et al. [22]. Bovine serum albumin was from Armour (Phoenix, Ariz) and all other chemicals were from Sigma (St. Louis, Mo).

\section{Cell culture}

The source and methods for culturing the L6 rat skeletal muscle cells have previously been described $[20,23]$. In brief, multiple vials of cells of similar passage were stored frozen in liquid nitrogen. A fresh vial was thawed every 3 weeks, and the myoblasts were maintained by repeat subculturing at low cell density in Eagle's Minimum Essential Medium (MEM) supplemented with $10 \%$ (vol/vol) bovine serum. For experiments, suspensions of myoblasts were prepared by incubation with Hank's balanced salt solution containing $0.1 \%$ trypsin and $0.5 \mathrm{mmol} / \mathrm{I}$ EDTA, and plated in $60 \mathrm{~mm}$ tissue culture dishes in $3 \mathrm{ml}$ of MEM with $10 \%$ bovine serum at a density of $7 \times 10^{3}$ cells/ $\mathrm{cm}^{2}$. The medium was replaced on the $4 \mathrm{th}, 7 \mathrm{th}, 8 \mathrm{th}, 9 \mathrm{th}, 10 \mathrm{th}, 11 \mathrm{th}$, and 14th days after plating. To stimulate differentiation and eliminate undifferentiated myoblasts, cytosine-1-beta-D-arabinofuranoside $\left(10^{-3} \mathrm{~mol} / \mathrm{l}\right)$ was added on the 8 th and 10 th days. This resulted in a non-replicating monolayer of skeletal myotubes that was used for experiments between the 15 th and 18 th days after plating.

\section{2-deoxyglucose uptake}

Cell monolayers were rinsed three times with glucose-free MEM supplemented with $1 \%$ bovine serum albumin and then incubated with the same medium for $22 \mathrm{~h}$ at $37^{\circ} \mathrm{C}$ prior to the determination of glucose uptake. To assure effective removal of surface-bound insulin, the cells were incubated for $30 \mathrm{~min}$ at $37^{\circ} \mathrm{C}$ between each wash.
Unless otherwise indicated, tolazamide was added at this time. After $14 \mathrm{~h}$ of further incubation, the medium was replaced with fresh medium containing the indicated concentrations of tolazamide and hormones. After an additional $8 \mathrm{~h}$ of incubation, the medium was removed and glucose uptake rate was determined by incubating for $10 \mathrm{~min}$ at room temperature $\left(22^{\circ} \mathrm{C}\right)$ in a modified Kreb's buffer $\left(122 \mathrm{mmol} / 1 \mathrm{NaCl}, 5 \mathrm{mmol} / 1 \mathrm{KCl}, 2.5 \mathrm{mmol} / 1 \mathrm{MgSO}_{4}, 1 \mathrm{mmol} / \mathrm{I}\right.$ $\mathrm{CaCl}_{2}, 1 \%$ bovine serum albumin, and $23 \mathrm{mmol} / 1$ Tris, $\mathrm{pH} 7.5$ ) containing the same concentration of hormone and ${ }^{14} \mathrm{C}-2-\mathrm{DG}(0.4 \mu \mathrm{Ci} /$ dish) at a final concentration of $0.16 \mathrm{mmol} / \mathrm{l}$. Uptake was stopped by removing the medium and rinsing three times with ice-cold Dulbecco's phosphate-buffered saline. The cells were solubilised with $1 \mathrm{~N} \mathrm{NaOH}$ and cell associated ${ }^{14} \mathrm{C}-2-\mathrm{DG}$ was determined by liquid scintillation counting. Protein content of the solubilised extracts was determined by a modification of the method of Lowry et al. [24]. Glucose uptake has previously been shown to be linear for more than $10 \mathrm{~min}$ under these conditions [20].

\section{Alpha-aminoisobutyric acid uptake}

Amino acid uptake was measured with the non-metabolisable substrate alpha-aminoisobutyric acid (AIB). The procedure was similar to that described for glucose uptake, except that regular MEM was utilised instead of glucose-free MEM. ${ }^{14} \mathrm{C}$ - $\mathrm{AIB}(0.1 \mu \mathrm{Ci} / \mathrm{dish})$ was added at a final concentration of $1.0 \mu \mathrm{mol} / 1$ and uptake was stopped after incubation for $20 \mathrm{~min}$ at $37^{\circ} \mathrm{C}$. AIB uptake was linear for more than $20 \mathrm{~min}$, with a $\mathrm{K}_{\mathrm{m}}$ of approximately $3 \mathrm{mmol} / \mathrm{l}$ in this cell line [25].

\section{Insulin binding}

The medium was removed from differentiated $\mathrm{L} 6$ myotubes in $60 \mathrm{~mm}$ dishes and, after rinsing three times with $2 \mathrm{ml}$ of binding buffer $\left(120 \mathrm{mmol} / 1 \mathrm{NaCl}, 5 \mathrm{mmol} / \mathrm{l} \mathrm{KCl}, 1.2 \mathrm{mmol} / 1 \mathrm{MgSO}_{4}\right.$, $10 \mathrm{mmol} / 1 \mathrm{NaHCO}_{3}, 1.3 \mathrm{mmol} / 1 \mathrm{CaCl}_{2}, 1.2 \mathrm{mmol} / 1 \mathrm{KH}_{2} \mathrm{PO}_{4}$, and $20 \mathrm{mmol} / \mathrm{I}$ HEPES, pH 7.8) at $37^{\circ} \mathrm{C}$, the monolayer was incubated for $4 \mathrm{~h}$ at $15^{\circ} \mathrm{C}$ with $2 \mathrm{ml}$ of binding buffer containing ${ }^{125} \mathrm{I}$-iodoinsulin $\left(2.5 \times 10^{-11} \mathrm{mmol} / \mathrm{l}\right)$ and additional unlabelled insulin as indicated. The medium was then removed, and the cells were washed with ice-cold Dulbecco's phosphate-buffered saline and solubilised with $1 \mathrm{~N} \mathrm{NaOH}$. Cell associated radioactivity was determined, and specific binding was expressed per mg protein [21]. The effect of tolazamide was studied by adding it to the medium at a concentration of $0.6 \mathrm{mg} / \mathrm{ml} 22 \mathrm{~h}$ before the binding assay and during the $4 \mathrm{~h}$ incubation with labelled hormone.

\section{Hormone degradation}

Degradation of insulin, IGF I and rat IGF II were measured as previously described [26]. Iodinated insulin $\left(10^{-7} \mathrm{~mol} / \mathrm{l}\right)$, IGF I $\left(10^{-8} \mathrm{~mol} / 1\right)$, or IGF II $\left(10^{-8} \mathrm{~mol} / 1\right)$ was incubated with cells at $37^{\circ} \mathrm{C}$ for $8 \mathrm{~h}$ in the presence or absence of tolazamide $(0.6 \mathrm{mg} / \mathrm{ml}$, $23 \mathrm{~h}$ ), and then precipitated by 10\% trichloroacetic acid (TCA) at $0^{\circ} \mathrm{C}$. The radioactivity associated with TCA-precipitable protein was recovered by centrifugation at $4^{\circ} \mathrm{C}$. Degradation of insulin before and after incubation was also studied by radioimmunoassay [27].

\section{Statistical analysis}

Data are presented as mean and standard deviation, with differences between groups tested by Student's t-test.

\section{Results}

\section{Effects of insulin and tolazamide on glucose uptake}

Cells of the L6 line grow in culture as undifferentiated myoblasts which, after reaching confluency, fuse into 

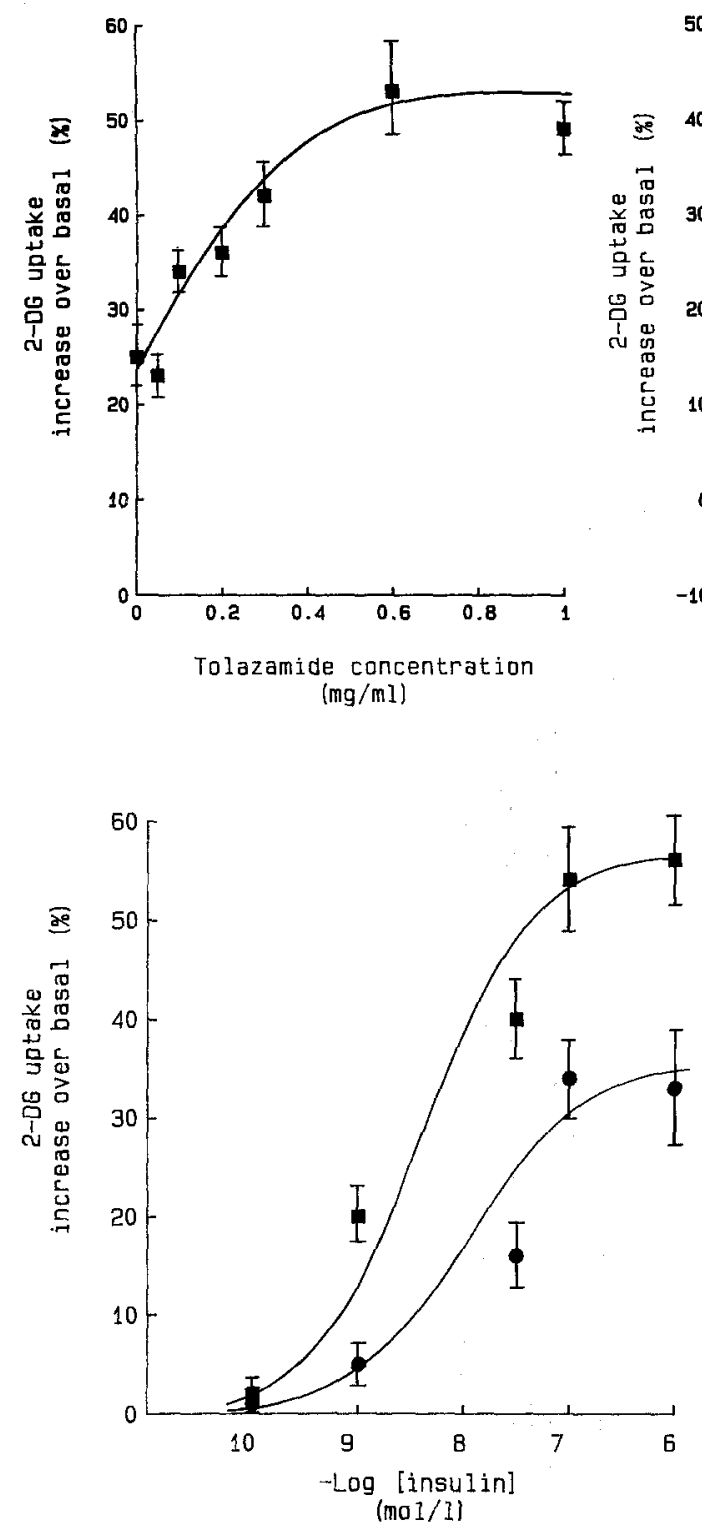

Fig. 2. Dose-response relationship between insulin concentration and glucose uptake in the presence and absence of tolazamide in differentiated L6 myotubes. Insulin was added to the medium at the indicated concentrations for the last $8 \mathrm{~h}$ of incubation. 2-DG uptake was measured in the presence ( $\mathbf{a}$ ) or absence ( $)$ of tolazamide $(0.6 \mathrm{mg} / \mathrm{ml}, 22 \mathrm{~h})$ as described in Materials and Methods. Basal 2-DG uptake was $0.33 \pm 0.07 \mathrm{nmol} \cdot \mathrm{mg}$ protein ${ }^{-1} \cdot \mathrm{min}^{-1}$. The data represent mean $\pm S D$ from four experiments in duplicate

post-mitotic, multinucleated myotubes with many characteristics of skeletal muscle $[23,28]$. By treating cultures with cytosine arabinoside at the time of fusion, it is possible to selectively eliminate residual myoblasts and obtain a homogeneous population of differentiated skeletal muscle myotubes [29]. Insulin stimulates glucose uptake in differentiated L6 skeletal muscle cells, with a maximal $40 \%$ increase above basal under these conditions at an insulin concentration of
$10^{-7} \mathrm{~mol} / \mathrm{l}$. As previously described [20], the effect reaches a maximum after 8 to $10 \mathrm{~h}$ of exposure to insulin.

When tolazamide was added to the culture medium for $22 \mathrm{~h}$ before the determination of glucose uptake, the effect of insulin was markedly augmented (Fig.1). Half-maximal stimulation of 2-DG uptake occurred at a tolazamide concentration of $0.2 \mathrm{mg} / \mathrm{ml}$, and the maximal effect required $0.6 \mathrm{mg} / \mathrm{ml}$ tolazamide. In the absence of insulin, tolazamide at concentrations as high as $0.6 \mathrm{mg} / \mathrm{ml}$ had no effect on glucose uptake. Thus, tolazamide augmented insulin action in a dose-dependent manner, but did not directly affect glucose uptake. The second generation sulfonylurea glyburide had a similar effect on insulin-stimulated glucose uptake but not basal glucose uptake, except that halfmaximal stimulation occurred at a much lower glyburide concentration $(0.5 \mu \mathrm{g} / \mathrm{ml})$.

Although insulin was required, the maximal effect of tolazamide occurred at low concentrations of insulin. As shown in Figure 2, there was no response to tolazamide at $10^{-10} \mathrm{~mol} / 1$ insulin, but a similar increase in glucose uptake at all concentrations between $10^{-9} \mathrm{~mol} / 1$ and $10^{-6} \mathrm{~mol} / 1$. Insulin sensitivity was increased, as evidenced by the 5-fold increment in glucose uptake with $10^{-9} \mathrm{~mol} / 1$ insulin. Even at saturating concentrations of insulin $\left(10^{-6} \mathrm{~mol} / 1\right)$, however, tolazamide still increased glucose uptake nearly 2 -fold. This stimulation of maximal efficacy is consistent with a post-binding mechanism of insulin action.

\section{Effects of insulin-like growth factors and tolazamide on glucose uptake}

The two insulin-like growth factors, IGF I and IGF II, both stimulate 2-DG uptake at low concentrations in 
A
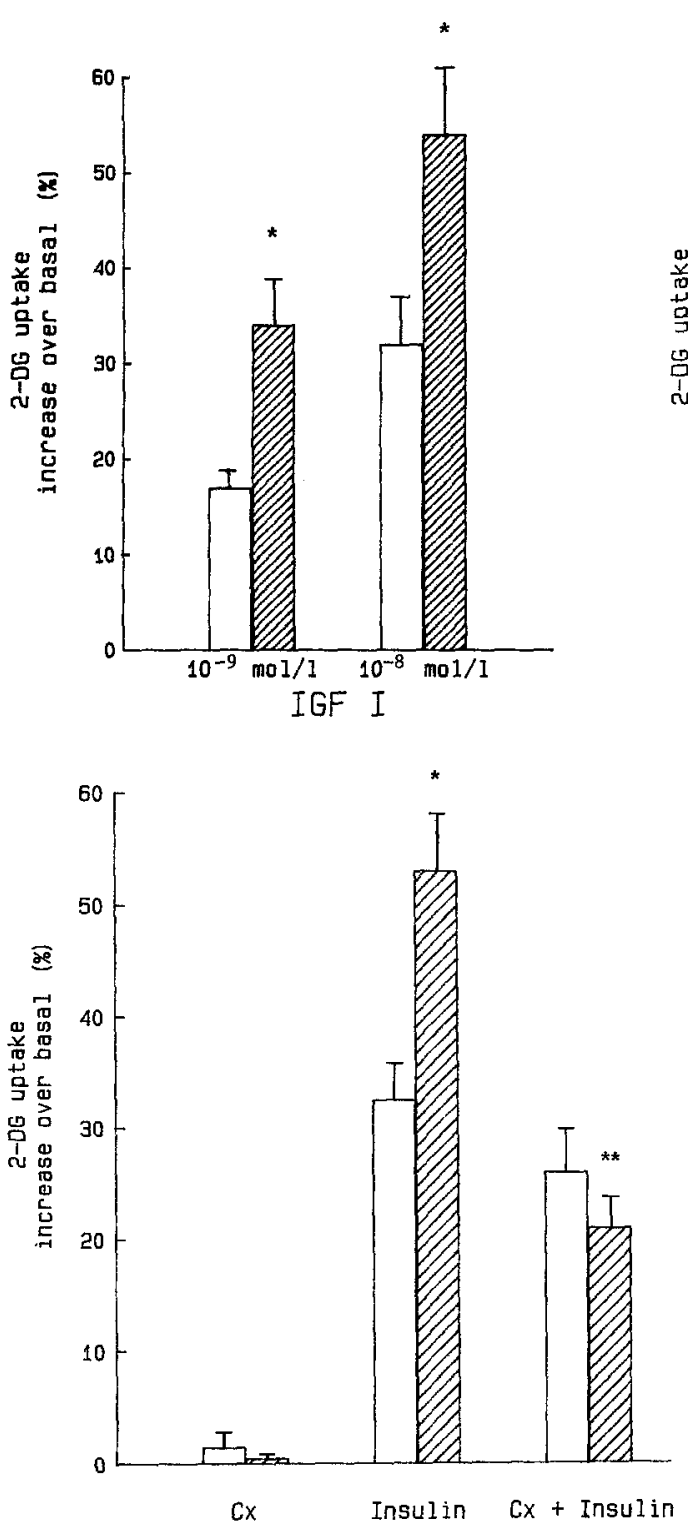

Fig. 4. Effects of cycloheximide on tolazamide action. Differentiated $\mathbf{L} 6$ myotubes were preincubated in the presence (hatched bars) or absence (open bars) of $0.6 \mathrm{mg} / \mathrm{ml}$ tolazamide for $22 \mathrm{~h}$. Insulin $\left(10^{-7} \mathrm{~mol} / \mathrm{l}\right)$ was added during the final $8 \mathrm{~h}$ of incubation as indicated. In bars labeled $\mathrm{Cx}$, cycloheximide $(500 \mu \mathrm{mol} / 1)$ was present during the first $14 \mathrm{~h}$ of pre-incubation and deleted during the final $8 \mathrm{~h}$. 2-DG uptake was then measured as described in Materials and methods. Basal 2-DG uptake was $0.32 \pm 0.04 \mathrm{nmol} \cdot \mathrm{mg}_{\text {protein }}{ }^{-1}$. $\min ^{-1}$. The data represent mean $\pm S D$ from three separate experiments in duplicate. Asterisks indicate statistically significant differences between tolazamide-treated and control groups by unpaired Student's t-test $\left({ }^{*} p<0.001 ;{ }^{* *} p<0.05\right)$

L6 cells (Fig. 3 A and B). It has previously been shown that the effect of each of these hormones on glucose uptake is mediated by distinct high affinity receptors [21]. As was the case for insulin, the stimulation of 2-DG uptake by IGF I and IGF II was augmented by tolazamide. Although tolazamide effects were only studied at two hormone concentrations, the similar increments in glucose uptake at low and maximal hor-
B

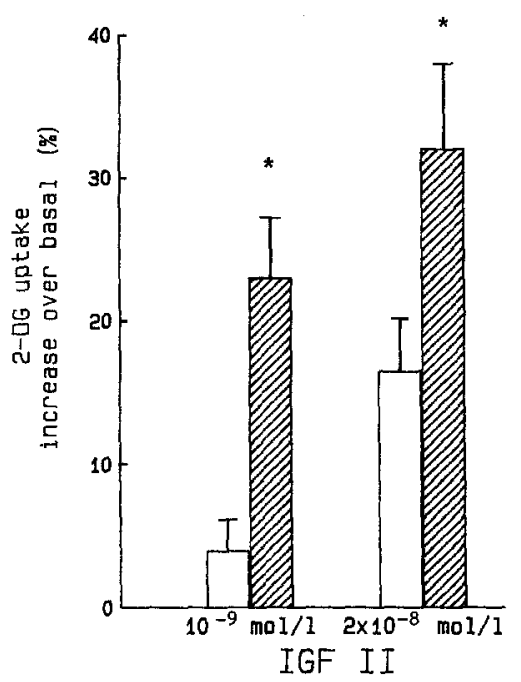

Fig. 3. Tolazamide effects on IGF I (A) and IGF II (B) stimulated 2-DG uptake in differentiated L6 myotubes. Cells were pre-incubated and 2-DG uptake was determined with (hatched bars) or without (open bars) tolazamide $(0.6 \mathrm{mg} / \mathrm{ml}, 22 \mathrm{~h})$ as described in Materials and methods. IGF's were added during the last $8 \mathrm{~h}$ of incubation at the indicated concentrations. Basal 2-DG uptake was $0.31 \pm 0.05 \mathrm{nmol} \cdot \mathrm{mg}$ protein ${ }^{-1} \cdot \mathrm{min}^{-1}\left(\right.$ pan- $^{-}$ el A) and $0.30 \pm 0.04 \mathrm{nmol} \cdot \mathrm{mg}$ protein $^{-1}$. $\min ^{-1}$ (panel B). The data represent mean \pm SD from three experiments in duplicate. Asterisks indicate statistically significant differences between tolazamide-treated and control groups by unpaired Student's t-test $(* p<0.001)$

mone concentrations are consistent with both increased sensitivity and increased maximal efficacy in response to tolazamide.

\section{Effect of cycloheximide on tolazamide responsiveness}

The effect of tolazamide on insulin-stimulated L6 cell glucose uptake required pre-incubation with the sulfonylurea for at least 8 to $10 \mathrm{~h}$, with maximal effects after $22 \mathrm{~h}$. To test the requirement for new protein synthesis during this relatively long exposure to tolazamide, cycloheximide $(500 \mu \mathrm{mol} / 1)$ was added during the first $14 \mathrm{~h}$ of the incubation with tolazamide. In separate experiments, this concentration of cycloheximide was shown to inhibit the incorporation of ${ }^{3} \mathrm{H}$-leucine into protein by more than $98 \%$ (data not shown). The protein synthesis inhibitor was removed by changing the medium at the time of addition of insulin, since previous experiments have shown that the long-term effect of insulin on 2-DG uptake is blocked by cycloheximide. As shown in Figure 4, cycloheximide pretreatment had no effect on the stimulation of 2-DG uptake by insulin. When present during the first $14 \mathrm{~h}$ of exposure to tolazamide, however, cycloheximide completely blocked the augmentation of insulin action. Thus, it is tentatively concluded that the effect of tolazamide on insulin-stimulated glucose uptake in L6 cells requires protein synthesis.

\section{Effect of insulin and tolazamide on AIB uptake}

Insulin stimulates a number of metabolic responses in addition to glucose uptake in L6 cells. For example, insulin has previously been shown to increase the uptake of the non-metabolisable amino acid analogue AIB $[20,21]$. To determine whether the augmentation of insulin-stimulated glucose uptake is associated with 


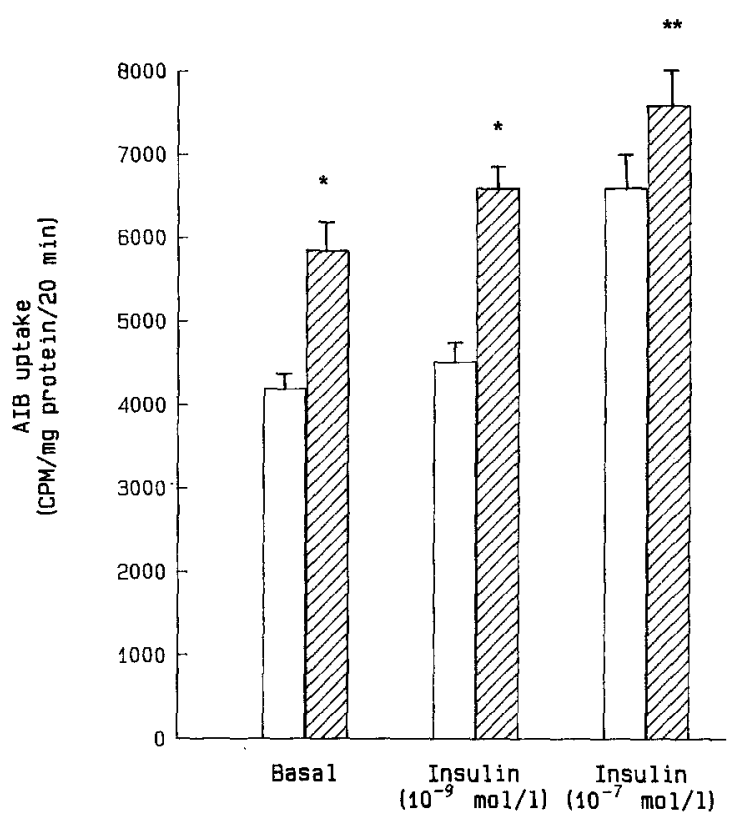

Fig. 5. Tolazamide effect on AIB uptake in L6 myotubes. Differentiated L6 myotubes were incubated with (hatched bars) or without (open bars) tolazamide $(0.6 \mathrm{ng} / \mathrm{ml}, 22 \mathrm{~h})$. Insulin $\left(10^{-9} \mathrm{~mol} / 1\right.$ or $10^{-7} \mathrm{~mol} / \mathrm{l}$ ) was added during the last $8 \mathrm{~h}$ of incubation as indicated. AIB uptake was then determined as described in Materials and methods. The data represent mean $\pm S D$ from two experiments in duplicate. Asterisks indicate statistically significant differences between tolazamide-treated and control groups by unpaired Student's t-test $(* p<0.001 ; * * p<0.01)$

changes in other insulin responses, the effect of tolazamide on AIB uptake was studied. In contrast to 2-DG uptake, the transport of AIB in L6 cells in the absence of insulin was increased by tolazamide (40\% increase with $0.6 \mathrm{mg} / \mathrm{ml}$ tolazamide) (Fig. 5). Although insulin also stimulated AIB uptake, the insulin effect was not significantly augmented by tolazamide. Protein content was not altered by insulin $(8 \mathrm{~h})$ or tolazamide $(22 \mathrm{~h})$.

\section{Effect of tolazamide on insulin binding}

L6 cells have previously been shown to have high-affinity cell surface binding sites for insulin [20]. At $15^{\circ} \mathrm{C}$, steady state binding is reached after $4 \mathrm{~h}$ of incubation with ${ }^{125} \mathrm{I}$-iodoinsulin. Under these conditions, the $\mathrm{K}_{\mathrm{d}}$ for insulin binding is $1.5 \times 10^{-9} \mathrm{~mol} / \mathrm{l}$. To determine whether the augmentation of insulin effects by tolazamide results from altered insulin binding, differentiated L6 myotubes were incubated for $22 \mathrm{~h}$ at $37^{\circ} \mathrm{C}$ in the presence or absence of $0.6 \mathrm{mg} / \mathrm{ml}$ tolazamide, and then the specific binding of insulin was determined. As shown in Figure 6, tracer insulin binding was unaffected by tolazamide treatment, and the competition curve with unlabelled insulin was superimposable with the curve from control cells. Thus, treatment with tolazamide under conditions known to augment insulin effects on glucose uptake does not alter insulin binding.

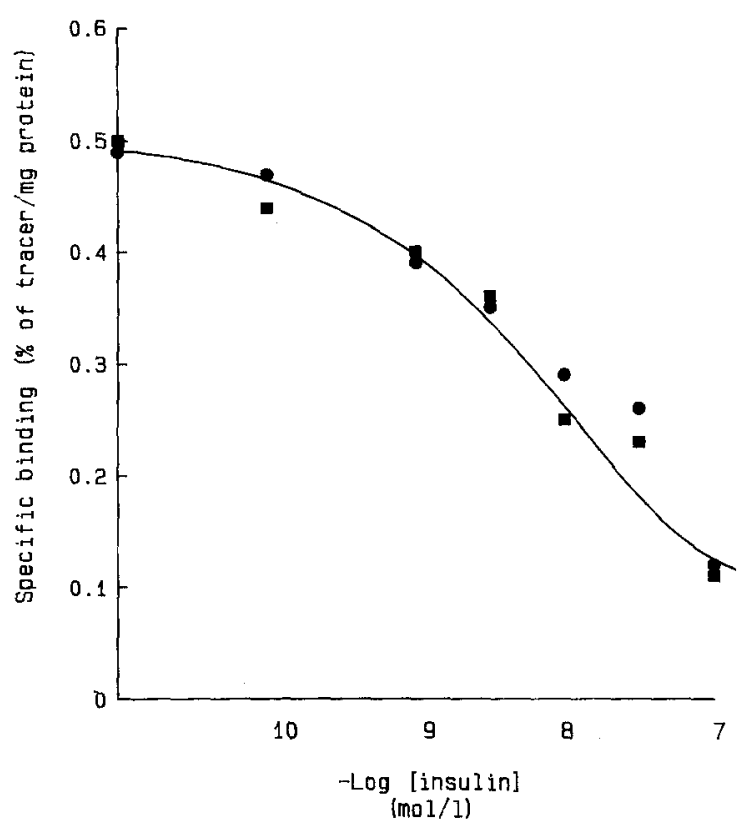

Fig. 6. Tolazamide effect on insulin binding in $\mathbf{L} 6$ myotubes. Differentiated myotubes were incubated with ${ }^{125} \mathrm{I}$-iodoinsulin and the indicated concentrations of unlabeled insulin for $4 \mathrm{~h}$ at $15^{\circ} \mathrm{C}$ after preincubation with $(\boldsymbol{\square})$ or without $(\mathbf{O})$ tolazamide $(0.6 \mathrm{mg} / \mathrm{ml}, 22 \mathrm{~h})$. Specific binding was then determined as described in Materials and methods. Each point represents the mean of 3 experiments in duplicate

\section{Effect of tolazamide on hormone degradation}

Hormone stability was assessed by quantifying TCAprecipitable radioactivity in the incubation media after exposing iodinated hormone to L6 cells. There was modest degradation (approx. 15\%) of IGF I $\left(10^{-8} \mathrm{~mol} / 1\right)$ and greater degradation (approx. $\left.45 \%\right)$ of insulin $\left(10^{-7} \mathrm{~mol} / \mathrm{l}\right)$ or IGF II $\left(10^{-8} \mathrm{~mol} / \mathrm{l}\right)$. However, tolazamide $(0.6 \mathrm{mg} / \mathrm{ml})$ did not alter the degradation rates of any of the hormones. When the insulin concentration $\left(10^{-7} \mathrm{~mol} / \mathrm{l}\right)$ before and after $8 \mathrm{~h}$ of incubation was further assessed by radioimmunoassay, it was found to be decreased by $40 \%$ without tolazamide and $45 \%$ with tolazamide $(0.6 \mathrm{mg} / \mathrm{ml})$, similar to the results with the TCA-precipitation method.

\section{Discussion}

The extrapancreatic actions of the sulfonylureas, which may play an important role in the pharmacologic action of these drugs, have been demonstrated in a number of different cell types. Relatively little is known about sulfonylurea effects on skeletal muscle, however, even though muscle is a quantitatively important site of insulin-stimulated glucose disposal [18] and a site of insulin resistance in non-insulin-dependent diabetes mellitus [30]. In studies on diaphragm muscle from rats [7] or mice [31], chronic treatment with tolbutamide has 
been shown to increase rapid insulin effects on glucose uptake without affecting basal glucose uptake. These findings differ from observations in the $\mathrm{BC} 3 \mathrm{H}-1$ cultured muscle cell line, in which glyburide, glypizide, and tolbutamide have been shown to increase basal glucose uptake but not to augment the effect of insulin $[14,32]$.

Glucose uptake by mammalian cells occurs through a carrier-mediated mechanism that is regulated by both rapid changes in the location or intrinsic activity of the glucose transporter, and longer term changes in the number of glucose transporters [19]. Studies in diabetic animals have demonstrated a decrease in the total number of glucose transporters that can be at least partially reversed by insulin treatment $[33,34]$, but the effects of sulfonylureas on long-term regulatory changes in glucose uptake have not been studied. For this reason, we evaluated the effects of sulfonylureas on glucose uptake chronically regulated by hormones in cultured skeletal muscle cells. We utilised L6 cells for these studies because they have previously been shown to have high-affinity insulin binding sites which mediate a number of biological responses after exposure to physiological levels of insulin [20,35]. In contrast to the central nervous system tumour-derived $\mathrm{BC} 3 \mathrm{H}-1$ cells, which exhibit a morphology suggestive of smooth muscle cells [36], the L6 cells appear to be more representative of skeletal muscle. They were initially derived from skeletal muscle of newborn rats and, during differentiation, undergo fusion into multinucleated, contracting myotubes [23].

In the L6 myotubes, the first generation sulfonylurea tolazamide causes a dose-dependent augmentation of insulin-stimulated glucose uptake. The halfmaximally effective concentration of $0.2 \mathrm{mg} / \mathrm{ml}$ is within the therapeutic range in humans [8]. As was the case with isolated rat and mouse diaphragm muscle, the sulfonylurea has no effect on basal glucose uptake, but increases responsiveness to insulin. This is characterised by increases in both the potency and the maximal effectiveness of insulin. Thus, the action of tolazamide in $\mathbf{L 6}$ cells parallels the effect observed in isolated skeletal muscle and differs from findings in the $\mathrm{BC} 3 \mathrm{H}-1$ cells. At lower concentrations consistent with its increased potency, the second generation sulfonylurea glyburide causes a similar increase in insulin-stimulated glucose uptake in L6 cells, indicating that the response occurs with other active sulfonylureas. This augmentation of chronic insulin stimulatory effects on glucose uptake in skeletal muscle cells by sulfonylureas may in part explain their therapeutic effects in Type II diabetes.

The increase in insulin-stimulated glucose uptake develops gradually, with a maximal effect after $22 \mathrm{~h}$ of exposure to tolazamide. This long preincubation time suggested a process requiring new protein synthesis, a possibility that was supported by studies with the protein synthesis inhibitor cycloheximide. When added during the first $14 \mathrm{~h}$ of incubation with tolazamide and then removed at the time of addition of insulin, cycloheximide does not alter the insulin effect, but it totally prevents the increase in insulin responsiveness secondary to tolazamide. It is unlikely that this requirement for protein synthesis can be simply equated with the formation of new glucose transporter molecules, since basal transport is unaffected by the sulfonylurea. Whether the inhibitory effect of cycloheximide is indicative of the synthesis of nonfunctional transporters that are activated by insulin or some other protein that augments insulin responsiveness remains to be determined. It is important to note that insulin itself has little effect on glucose uptake after brief exposure of L6 cells under these conditions, with a maximal response requiring 8 to $10 \mathrm{~h}$ of incubation with insulin [20]. Thus, although rapid insulin effects can be demonstrated in L6 cells under different experimental conditions [35], it is unlikely that increased glucose uptake in the present studies results from a simple translocation of glucose transporters [19].

Whatever the mechanism through which sulfonylureas increase insulin-stimulated glucose uptake, it appears also to affect responsiveness to the homologous hormones IGF I and IGF II. The action of low and high concentrations of these hormones is increased by tolazamide, suggesting that both sensitivity and maximal efficacy of IGF I and IGF II are increased. Previous studies in L6 cells have demonstrated that distinct insulin, IGF I, and IGF II receptors mediate the actions of these hormones on glucose uptake [21]. The effects of tolazamide at low IGF concentrations suggest that the actions of all three receptors are modified by the sulfonylurea. Since insulin binding and insulin and IGF degradation are unaffected by tolazamide in the L6 cells, it is likely that increased hormone action occurs through a post-binding mechanism. This could result from modifications in the three types of hormone receptors, the glucose transporter, or yet undefined pathways through which transporter function is altered.

In addition to its effects on glucose uptake in L6 cells, tolazamide also increases uptake of the non-metabolisable amino acid analogue AIB. In contrast to the effects on glucose uptake, however, only basal AIB uptake is stimulated by tolazamide. Insulin itself increases AIB uptake, but its effect is not augmented by the sulfonylurea. An increase in basal AIB uptake without alterations in insulin-stimulated AIB uptake in response to tolazamide has recently been observed in mouse skeletal muscle [14], further establishing the similarities betwen L6 cells and mature skeletal muscle. This cultured skeletal muscle cell line should be useful in future studies on the mechanism of the extrapancreatic actions of sulfonylureas.

Acknowledgements. The authors wish to thank Dr. A. Moses from the Beth Israel Hospital in Boston, Mass, USA for providing rat IGF II and the Upjohn Company, Kalamazoo, Mich, USA, for providing 
sodium tolazamide and potasssium glyburide. This work was supported in part by a grant from Upjohn. Dr. P.H. Wang is supported by a postdoctoral fellowship from the Juvenile Diabetes Foundation.

\section{References}

1. Loubatieres A (1944) Relations entre la structure moleculaire et l'activite hypoglycemiante des aminosulfamides hypoglycemiantes. Arch Int Physiol 54: 174-177

2. Pfeiffer EF, Pfeiffer M, Ditshunest H, Kahn C (1959) Clinical and experimental studies of insulin secretion following tolbutamide and metahexamide administration. Ann NY Acad Sci 82: 479-495

3. Levine R (1984) Sulfonylureas: background and development of the field. Diabetes Care 7: 3-7

4. Reaven G, Dray J (1967) Effect of chlorpropamide on serum glucose and immunoreactive insulin concentrations in patients with maturity onset diabetes mellitus. Diabetes 16: 487-492

5. Ward G, Harrison L, Proietto J, Aitken P, Nankervis A (1985) Gliclazide therapy is associated with potentiation of post-binding insulin action in obese non-insulin dependent diabetic subjects. Diabetes 34: 241-245

6. Simonson D, Ferrannini E, Stefano S, Smith D, Barret E, Carlson R, DeFronzo R (1984) Mechanism of improvement in glucose metabolism after chronic glyburide therapy. Diabetes 33 : $835-838$

7. Feldman J, Lebovitz H (1969) An insulin-dependent effect of chronic tolbutamide administration on the skeletal muscle carbohydrate transport system. Diabetes 18: 84-95

8. Maloff B, Lockwood D (1981) In vitro effects of a sulfonylurea on insulin action in adipocytes: potentiation of insulin-stimulated hexose transport. J Clin Invest 68: 85-90

9. Zuber MX, Wang SM, Thammavaram KV, Reed DK, Reed BC (1985) Elevation of the number of cell-surface insulin receptors and the rate of 2-deoxyglucose uptake by exposure of 3T3-L1 adipocytes to tolbutamide. J Biol Chem 260: 14045-14152

10. Vigneri R, Pezzino V, Wong KY, Goldfine ID (1982) Comparison of biguanides and sulfonylureas: effect on insulin receptors in vitro. J Clin Endocrinol Metab 54: 95-100

11. Prince MJ, Olefsky JM (1980) Direct in vitro effect of a sulfonylurea to increase human fibroblast insulin receptors. J Clin Invest 66: 608-611

12. Salhanick A, Konowitz P, Amatruda J (1983) Potentiation of insulin action by a sulfonylurea in primary cultures of hepatocytes from normal and diabetic rats. Diabetes 32: 206-212

13. Rinninger F, Kirsch D, Haring HU, Kemmler W (1984) Extrapancreatic action of the sulphonylurea gliquidone: post-receptor effect on insulin-stimulated glycogen synthesis in rat hepatocytes in primary culture. Diabetologia 26: 462-465

14. Gavin JR (1985) Dual actions of sulfonylureas and glyburide. Receptor and post-receptor effects. Am J Med 79 [Suppl 3 B]: 34-42

15. Editorial (1985) Combined sulfonylurea and insulin therapy in insulin-dependent diabetes: research or clinical practice? Diabetes Care 8: $511-514$

16. Olefsky JM, Reaven GM (1976) Effects of sulfonylurea therapy on insulin binding to mononuclear leukocytes of diabetic patients. Am J Med 60: 89-95

17. Beck-Nielsen H, Pedersen O, Lindskov HO (1979) Increased insulin sensitivity and cellular insulin binding in obese diabetics following treatment with glibenclamide. Acta Endocrinol 90: $451-462$

18. DeFronzo RA, Ferrannini E, Hendler R, Felig P, Wahren J (1983) Regulation of splanchnic and peripheral glucose uptake by insulin and hyperglycemia in man. Diabetes $32: 35-45$
19. Simpson IA, Cushman SW (1986) Hormonal regulation of mammalian glucose transport. Ann Rev Biochem 55: 1059-1089

20. Beguinot F, Kahn CR, Moses AC, Smith RJ (1986) The development of insulin receptors and responsiveness is an early marker of differentiation in the muscle cell line L6. Endocrinology 118: 446-455

21. Beguinot F, Kahn CR, Moses AC, Smith RJ (1985) Distinct biologically active receptors for insulin, insulin-like growth factor I, and insulin-like growth factor II in cultured skeletal muscle cells. J Biol Chem 260: 15892-15898

22. Moses AC, Nissley SP, Short PA, Rechler MM, Podskalny JM (1980) Purification and characterization of multiplication-stimulating activity. Insulin-like growth factors purified from rat-livercell conditioned medium. Eur J Biochem 103: 387-400

23. Yaffe D (1968) Retention of differentiation potentialities during prolonged cultivation of myogenic cells. Proc Natl Acad Sci 61: 477-483

24. Lowry OH, Rosebrough NJ, Farr AL, Randall RJ (1951) Protein measurement with the Folin phenol reagent. J Biol Chem 193: 265-275

25. Merril G, Florini JR, Dulak N (1977) Effect of multiplication stimulating activity (MSA) on AIB transport into myoblast and myotube cultures. J Cell Physiol 93: 173-182

26. Jialal I, King GL, Buchwald S, Kahn CR, Crettaz M (1984) Processing of insulin by bovine endothelial cells in culture. Diabetes 33: 794-800

27. Yalow RS, Berson SA (1960) Immunoassay of endogenous plasma insulin in man. J Clin Invest 39: 1157-1175

28. Shainberg A, Yagil G, Yaffe D (1971) Alterations of enzymatic activities during muscle differentiation in vitro. Dev Biol 25: 1-29

29. Smith RJ, Larson S, Stred SE, Durschlag RP (1984) Regulation of glutamine synthetase and glutaminase activities in cultured skeletal muscle cells. J Cell Physiol 120: 197-203

30. Olefsky JM, Ciaraldi TP (1981) The insulin receptor: basic characteristics and its role in insulin-resistant states. In: Brownlee $\mathrm{M}$ (ed) Diabetes Mellitus, Vol 2. Garland STM Press, New York, p $73-116$

31. Banerji M, Lebovitz HE (1986) Direct effect of sulfonylureas on amino acid transport in muscle. Diabetes 35 [Suppl 1]: 65A

32. Pollet RJ, Rogers BJ (1986) Effects of sulfonylurea drugs on 2-deoxy glucose transport in the $\mathrm{BC} 3 \mathrm{H}-1$ myocyte. Diabetes 35 [Suppl 1]: 164A

33. Karnieli E, Hissin PJ, Simpson IA, Salans LB, Cushman SW (1981) A possible mechanism of insulin resistance in the rat adipose cell in streptozotocin-induced diabetes mellitus. Deletion of intracellular glucose transport systems. J Clin Invest 68: 811-814

34. Kahn BB, Cushman SW (1985) Markedly hyperresponsive insulin-stimulated glucose uptake in adipocytes induced by insulin therapy of streptozotocin diabetic rats: increased glucose transporter number and activity. Clin Res 33: 433 A

35. Klip A, Li G, Logan WJ (1984) Induction of sugar uptake response to insulin by serum depletion in fasting L6 myoblasts. Am J Physiol 247: E291-296

36. Standaert ML, Schimmel SD, Pollet RJ (1984) The development of insulin receptors and responses in the differentiating nonfusing muscle cell line BC3H-1. J Biol Chem 259: 2337-2345

Received: 18 May 1987

and in revised form: 2 September 1987

Dr. Robert J.Smith

Joslin Research Laboratory

One Joslin Place

Boston, MA 02215

USA 